\title{
ВИВЧЕННЯ ТОКСИЧНОГО ВПЛИВУ КАДМІЮ ХЛОРИДУ НА ОРГАНІЗМ ПІДДОСЛІДНИХ ТВАРИН В УМОВАХ ГОСТРОГО ДОСЛІДУ
}

\author{
СН. В. Флекей
}

\section{ДВНЗ «Тернопільський державний медичний університетімені І. Я. Горбачевського МОЗ України»}

РЕЗЮМЕ. Вивчено токсичність впливу кадмію хлориду на організм піддослідних тварин в умовах гострого досліду. Досліджено морфологічні зміни в печінці та нирках у білих щурів при вживанні питно води з різними концентраціями кадмію хлориду.

КЛЮЧОВІ СЛОВА: нирки, печінка, кадмію хлорид, питна вода

Вступ. Проблема якості довкілля сьогодні перетворилася на життєво важливу проблему. Антропогенне навантаження досягло критичного рівня [1-6]. Більшість хімічних речовин, які попадають у водойми з промисловими стічними водами, можуть потрапляти в організм людей і стати причиною захворювання. До таких речовин можна віднести кадмій. Основними джерелами забруднення довкілля важкими металами, в тому числі й кадмієм, є викиди теплоенергетичних підприємств, заводів з переробки відходів та газоподібні викиди чорно та кольорово металургі, забруднення транспортом. У літературі $\epsilon$ повідомлення і про життєву необхідність кадмію в нетоксичних концентраціях - він регулює рівень цукру в крові, стимулює ріст тварин, дефіцит кадмію в раціоні викликає затримку росту та статевого дозрівання. Токсична доза кадмію для людини коливається від 3 до 330 міліграм, а летальна 1,5-9 г. Цей метал має також онкогенні властивості [4].

Метою нашого дослідження було вивчення токсично ді кадмію хлориду на організм білих щурів в умовах гострого досліду.

Матеріал і методи дослідження. Дослідження проведено на 12 білих безпородних щурах масою 180-200 г. Гостру токсичність хлориду кадмію на білих щурах-самках вивчали експрес-методом. До початку досліду тварин зважували, розраховували необхідну кількість кадмію хлориду, готували потрібну кількість розчину певно концентраці . Вводили 2,5\% водний розчин кадмію хлориду піддослідним тваринам внутрішньошлунково з розрахунку на кадмій: першій групі - 63,0 мг/кг; другій 66,8 мг/кг; третій - 70,8 мг/кг. Четвертій групі тварин вводили аналогічну кількість води. Кожна група складалася з 3 тварин. Експеримент проводили згідно з вимогами біоетики. Дія препарату проявлялася через 10-15 хвилин після введення.

Спочатку спостерігалась стадія збудження. Через 30 хвилин наставала друга стадія - пригнічення, що характеризувалась сонливістю, адинамією, тварини забивалися у куток клітки. 3'являлися ціаноз лапок, судомні посмикування, дискоординація рухів, полідипсія, згодом у тварин наставали конвульсивні судоми та смерть. У першій групі з трьох тварин загинув один щур, у другій і третій групах з однаково кількості тварин загинуло по дві тварини впродовж 2-х діб (табл. 1). В усіх випадках смерть наставала в основному внаслідок гепатонефрально недостатності.

Таблиця 1. Динаміка загибелі білих щурів-самок після введення у шлунок кадмію хлориду

\begin{tabular}{|c|c|c|c|c|c|c|c|}
\hline \multirow{2}{*}{$\begin{array}{l}\text { Дози, } \\
\text { Мг/кг }\end{array}$} & \multirow{2}{*}{$\begin{array}{c}\text { К-ть } \\
\text { тварин }\end{array}$} & \multirow{2}{*}{ Ефект дії } & \multicolumn{4}{|c|}{ Строки спостереження, доби } & \multirow{2}{*}{$\begin{array}{c}\text { К-ть } \\
\text { загиблих тварин }\end{array}$} \\
\hline & & & 1 & 2 & 3 & 15 & \\
\hline 63,0 & 3 & $3 / 0$ & 0 & 0 & 0 & 0 & 0 \\
\hline 63,0 & 3 & $3 / 0$ & 0 & 0 & 0 & 0 & 0 \\
\hline 63,0 & 3 & $3 / 1$ & 1 & 0 & 0 & 0 & 1 \\
\hline 66,8 & 3 & $3 / 0$ & 0 & 0 & 0 & 0 & 0 \\
\hline 66,8 & 3 & $3 / 1$ & 0 & 0 & 0 & 0 & 1 \\
\hline 66,8 & 3 & $3 / 1$ & 1 & 0 & 0 & 0 & 1 \\
\hline 70,8 & 3 & $3 / 1$ & 1 & 0 & 0 & 0 & 1 \\
\hline 70,8 & 3 & $3 / 1$ & 1 & 0 & 0 & 0 & 1 \\
\hline 70,8 & 3 & $3 / 0$ & 0 & 0 & 0 & 0 & 0 \\
\hline
\end{tabular}

Результати й обговорення. Далі, згідно з таблицею «ЛД середню смертельну дозу з довірчими границями. Таким чином було встановлено, що ЛД до дл кадмію хлориду (в розрахунку на кадмій), становить
65,6 (59,4-71,7) мг/кг, що практично відповідає літературним даним - 67 мг/кг. У щурів, які залишилися живими, загальний стан поліпшився, і на 3-5 добу вони вже майже не відрізнялись від контрольних. 


\section{Оеляди літератури, ориаінальні дослідження, поеляд на проблему}

Протягом 14 днів спостерігали за станом тварин. Три тварини загинули через 15-60 хвилин після введення хлориду кадмію, одна через 24 години і останні 5 через 36 годин від початку досліду. Індекс кумуляці розрахований за Б. М. Штабським, з врахуванням кількості тварин, що загинули в умовах гострого досліду протягом першо доби і впродовж усього періоду спостереження - 14 діб. Індекс кумуляці розраховували за наступною формулою: I кум.=1-Д $/ Д_{1}$, де $Д_{1}-$ смертність тварин за 1 добу; Д - смертність тварин протягом 14 днів.

к кум=1-5/4=1-1,25=0,75. При патоморфологічному дослідженні внутрішніх органів тварин, які загинули, було встановлено збільшення в розмірах нирок з вираженим повнокров'ям судин. у нирках повнокров'я судин спостерігалося переважно у кірковій зоні. При експериментальному отруєнні білих щурів-самок кадмієм у нирках спостерігали зміни як у тубулярному, так i в гломерулярному апаратах. При цьому х капсула збільшувалась, а площа судинного клубочка зменшувалась, вільний просвіт капсули розширювався, що вплинуло на розташування ядер у клітинах (рис. 1).

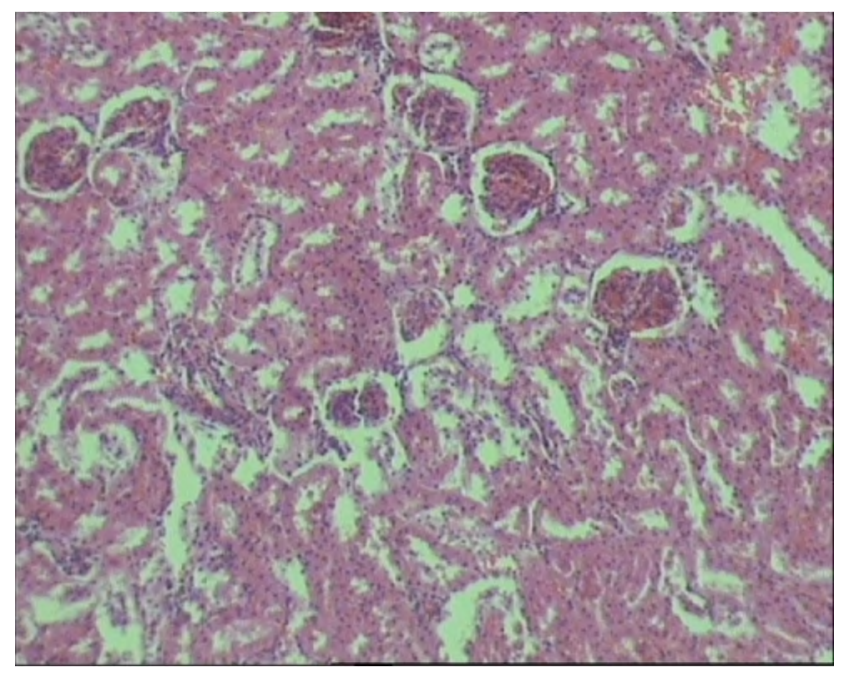

Рис. 1. Гістологічна структура нирки при гострому отруєнні білих щурів кадмію хлоридом. Епітелій проксимальних і дистальних канальців набряклий, із ознаками гідропічно дистрофі . Гіпертрофія нирково капсули. Забарвлення гематоксиліном та еозином × 200. Строма навколо канальців помірно інфільтрована лімфо- і гістіоцитами. Судини розширені, із ознаками стазів, містять помірну кількість еритроцитів, із дрібними периваскулярними крововиливами. При цьому в просвітах капсул, окрім набряку, часто зустрічаються білкові депозити, які спричиняють х розширення. Ендотеліоцити із ознаками білково дистрофі. Базальні мембрани потовщені, набряклі. Епітелій проксимальних канальців із ознаками гіаліновокрапельно дистрофі, частина його десквамована і міститься у просвітах канальців, частина у стаді репаративно регенераці.
Структура печінки представлена часточковою будовою. В центролобулярних відділах гепатоцити збільшені в об'ємі, х ядра профарбовуються слабо, іноді спостерігаються явища каріолізису, що свідчить про вогнищевий колікваційний некроз. У печінці також відзначали розширення і повнокров'я судин, крововиливи і набряк строми, відмічалися явища периваскулярного набряку, місцями - невеликі клітинні інфільтрати, у гепатоцитах - прояви білково дистрофі . Такі зміни виникають за рахунок порушення водно-електролітного обміну. В периферійних гепатоцитах спостерігається поява в цитоплазмі помірних гіаліноподібних білкових включень, які зливаються і заповнюють всю цитоплазму клітини, або розміщуються дифузно, що свідчить про глибоку денатурацію білків цитоплазми. Також зустрічаються і моноцелюлярні некрози, які завершуються коагуляційним некрозом. При цьому гепатоцити зменшені в розмірах, зморщені, із щільною гомогенною цитоплазмою, еозинофільні, з пікнотичними ядрами (рис. 2).

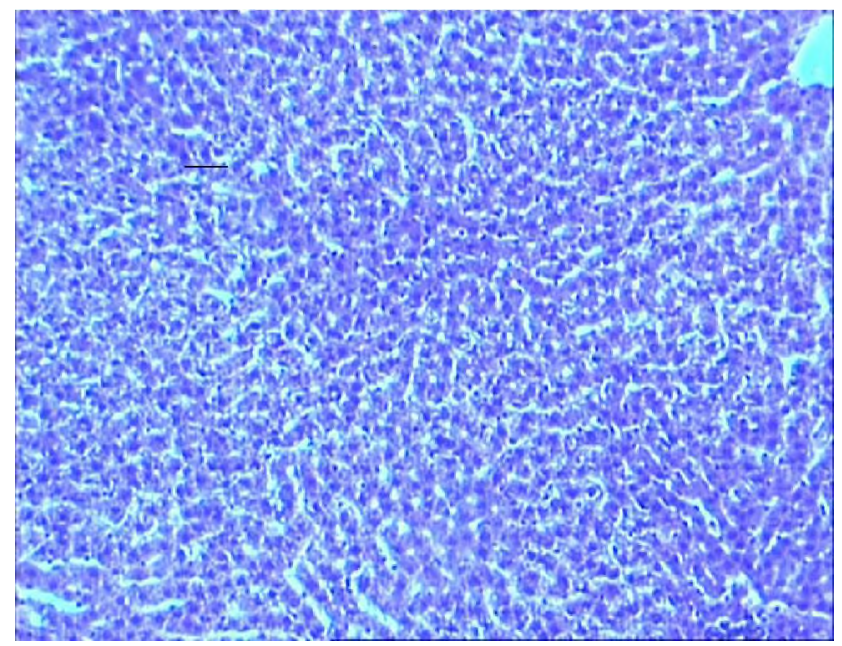

Рис. 2. Гістологічна структура печінки при моделюванні кадмієвого отруєння. Гепатоцити зменшені в розмірах, зморщені, із щільною цитоплазмою, еозинофільні з пікнотичними ядрами. Забарвлення гематоксиліном та еозином х 200.

Висновки. 1. Проведені нами дослідження свідчать, що кадмію хлорид $є$ високотоксичною і висококумулятивною речовиною (2-й клас токсичності), що вимагає подальшого вивчення його впливу на організм піддослідних тварин не тільки в умовах гострого санітарно-токсикологічного експерименту, але у більш тривалому досліді в комбінаці з іншими складниками питно води, наприклад натрію хлориду, з використанням сучасних методів дослідження.

2. Вивчено токсикологічні властивості кадмію хлориду на організм піддослідних тварин при надходженні в організм з питною водою в різних концентраціях. 
Оеляди літератури, ориаінальні дослідження, поеляд на проблему

ЛIТЕРАТУРА

1. Сердюк А. М. Гігієнічні проблеми Укра ни на рубежі століть / А. М. Сердюк // Гігієнічна наука і практика на рубежі століть : XIV з' зд гігієністів Укра ни: матеріали ; під ред. Ю. І. Кундієва, А. М. Сердюка, Є. Г. Гончарука, О. В. Лопушенко. - Дніпропетровськ : АРТ-ПРЕС, 2004. C. $30-33$.

2. Прокопов В. О. Першочергові задачі гігієни у сфері питно води та питного водопостачання, спрямовані на виконання загальнодержавно програми «Питна вода Укра ни» / В. О. Прокопов // Актуальні питання гігієни та екологічно безпеки Укра ни. - 2006. C. $26-27$.

3. Сердюк А. М. Екологічна ситуація в Укра ні і здоров'я людини: теперішній стан та шляхи профілактики /
А. М. Сердюк //Журнал Академі медичних наук. - 1997. № 2. - C. $218-230$

4. Антропогенне забруднення довкілля кадмієм і вплив його на організм ссавців / Кондратюк В. А., Кубант Р. М., Лотоцька О. В. [та ін.] // Гігієна населених місць. - К., 2006. - C. 97-104.

5. Прокопов В. О. Розробка національних стандартів на водопровідну та фасовану питну воду - шлях до покращення стану питного водопостачання населення / В. О. Прокопов, О. В. Зоріна, С. І. Загайський // Актуальні питання гігієни та екологічно безпеки Укра ни. - К., 2007. - С. 15-16.

6. Гончарук В. В. Проблеми забезпечення населення Укра ни питною водою / В. В. Гончарук, В. Ф. Скубченко // Колега. - 2001. - № 3. - С. 11-14.

\section{DETERMINATION OF TOXICITY OF CADMIUM CHLORIDE ON RATS ORGANISM IN CONDITION OF ACUTE EXPERIMENTS}

\section{(C). V. Flekey}

\section{SHEl «Ternopil State Medical University by I. Ya. Horbachevsky of MPH of Ukraine»}

SUMMARY. Toxicity of cadmium chloride on rats organism in condition of acute experiment was determined. Morphological changing in the liver and kidneys of white rats during drinking water with different concentration of cadmium chloride was researched.

KEY WORDS: kidneys, liver, cadmium chloride, drinking water. 